\title{
The Effect of Financial Literature and Financial Inclusion on Family Welfare
}

\author{
I Putu Agus Santana ${ }^{1 *}$, \& Ida Bagus Putu Purbadharmaja ${ }^{2}$ \\ ${ }^{1}$ Faculty of Economics and Business, Udayana University, Indonesia \\ ${ }^{2}$ Faculty of Economics and Business, Udayana University, Indonesia \\ DOI - http://doi.org/10.37502/IJSMR.2022.5207
}

\begin{abstract}
Lack of access to services and a basic understanding of finance is a widespread problem throughout the world, including Indonesia. According to data, only 36 percent of Indonesian adults, or approximately 90 million people, have bank accounts (World Bank Data, 2017). This statistic is significantly lower than Malaysia's 81 percent, China's 79 percent, and India's percent (Global Findex, 2017). The following study will examine poverty and welfare conditions in Indonesia, followed by an examination of the impact of financial literacy and inclusion on family welfare. This study employs a descriptive method to sift through the available literature on welfare and issues relating to Financial Literacy and Inclusion in Indonesia. Financial literacy has the potential to have a detrimental effect on family welfare. Financial inclusion has the potential to provide numerous benefits to the community, regulators, government, and private sector, ultimately resulting in poverty reduction. In practice, this research can be used to help increase household financial literacy and inclusion in Indonesia, where these indicators remain low.
\end{abstract}

Keywords: financial literacy, financial inclusion, family welfare

\section{Introduction}

To assist in accelerating equitable economic growth and eradicating poverty, the financial sector's contribution must be maximized by broadening public access to financial services. According to Hasan (2020), the household is one of the most significant financial actors. However, household finance research receives relatively little attention in comparison to other areas of finance, such as companies, investments, banking, institutions, and financial markets. Campbell (2006) emphasizes the importance of conducting more in-depth research on household finances, using both positive and normative approaches. The use of financial products, which is frequently referred to as financial inclusion, is a critical behavior in household finance. Financial inclusion is thought to promote economic and financial growth, as well as efforts toward equity and inequality reduction (Sachdeva and Gupta, 2014).

Lack of access to services and a basic understanding of finance is a widespread problem throughout the world, including Indonesia. According to Lusardi and Mitchell (2007), low financial literacy is a global phenomenon. According to the World Bank's 2015 Global Financial Inclusion Index, Indonesia has relatively low access to formal finance when compared to other Southeast Asian countries. According to Gabaix and Laibson (2006), the presence of uneducated households and confusion regarding the use of financial products 
results in cross subsidies from naive households to households that have a better understanding of financial products (sophisticated households).

According to data, only $36 \%$ of Indonesian adults, or approximately 90 million people, have bank accounts (World Bank Data, 2017). This figure is significantly lower than Malaysia's 81 percent, China's 79 percent, and India's 53\%. (Global Findex, 2017). According to a 2015 World Bank survey, Indonesia's high rate of unbanked people can be explained on two aspects: demand and supply. On the supply side, several factors impede public access to financial services, including asymmetric information that causes financial institutions to be overly selective. in selecting customers, the establishment of branch offices that are often prohibitively expensive, the perception of housewives with low incomes who lack access to financial services, the establishment process is stymied by bureaucracy, excessive formality, and complex problems, the view of grassroots customers is deemed unprofitable, the requirement for support from IT systems such as expanding communication networks. World Bank (2015), cited in Sanistasya et al (2018).

The third National Financial Literacy and Inclusion Survey (SNLIK) conducted by the Financial Services Authority (OJK) in 2019 has shown a Financial Literacy Index of 38.03\% and a Financial Inclusion Index of 76.19\%. This figure represents an increase over the 2016 OJK survey results, which indicated a Financial Literacy Index of 29.7 percent and a Financial Inclusion Index of 67.8 percent. The government's goal with the Innovative Financial Inclusion Promotion Program is to increase the percentage of Indonesians who use financial products or services from formal financial institutions from $76 \%$ in 2019 to $90 \%$ in 2022.

While the generalization of the Literacy and Inclusion index has increased over time, there is a fairly significant gap between the Financial Inclusion and Financial Literacy indices. The panic in penetrating finance without providing economic actors with adequate economic skills and knowledge requires attention from a variety of stakeholders. The research's recommendations for Nigeria include not only expanding financial inclusion efforts through increased credit delivery to the private sector, but also strengthening the regulatory framework to ensure resource allocation and utilization are efficient and effective.

According to Hasan (2020), the household is one of the most significant financial actors. However, household finance research receives relatively little attention in comparison to other areas of finance, such as companies, investments, banking, institutions, and financial markets. Campbell (2006) emphasizes the importance of conducting more in-depth research on household finances, using both positive and normative approaches. The use of financial products, which is frequently referred to as financial inclusion, is a critical behavior in household finance. Financial inclusion is thought to promote economic and financial growth, as well as efforts toward equity and inequality reduction (Sachdeva and Gupta, 2014).

While financial literacy in Indonesia is still considered to be quite low, the government of Indonesia places considerable emphasis on it through the Financial Services Authority (OJK), a state regulatory body. Additionally, there is an imbalance in the province's Financial Inclusion Index and Financial Literacy, indicating that there are obstacles in the field that must be analyzed in terms of their causes, effects, and various economic regulation scenarios. The Financial Literacy Index for each province in 2016 and 2019 is shown in Figure Table 1 below. 
Table 1. Index of Financial Literacy and Inclusion in Indonesia and the Difference between 2016 and 2019 by Province.

\begin{tabular}{|c|c|c|c|c|c|c|c|}
\hline \multirow[t]{2}{*}{ No } & \multirow[t]{2}{*}{ Provinsi } & \multicolumn{3}{|c|}{2016} & \multicolumn{3}{|c|}{2019} \\
\hline & & Literasi & Inklusi & Timpang & Literasi & Inklusi & Timpang \\
\hline 1 & DKI Jakakarta & 40 & 78.2 & 38.2 & 59.16 & 94.76 & 35.6 \\
\hline 2 & DI Yogyakarta & 38.5 & 76.7 & 38.2 & 58.53 & 76.12 & 17.59 \\
\hline 3 & Banten & 38.2 & 69.5 & 31.3 & 39.27 & 84.29 & 45.02 \\
\hline 4 & Bali & 37.5 & 76 & 38.5 & 38.06 & 92.91 & 54.85 \\
\hline 5 & Kepulauan Riau & 37.1 & 74.5 & 37.4 & 45.67 & 92.13 & 46.46 \\
\hline 6 & Jawa Timur & 35.6 & 73.2 & 37.6 & 48.95 & 87.96 & 39.01 \\
\hline 7 & Jawa Tengah & 33.5 & 66.2 & 32.7 & 47.38 & 65.71 & 18.33 \\
\hline 8 & Jawa B arat & 33 & 71.4 & 38.4 & 37.43 & 88.48 & 51.05 \\
\hline 9 & Aceh & 32.7 & 73.1 & 40.4 & 44.36 & 86.09 & 41.73 \\
\hline 10 & Sumatera Selatan & 31.3 & 72.4 & 41.1 & 40.05 & 85.08 & 45.03 \\
\hline 11 & Sumatera Utara & 31.3 & 75.6 & 44.3 & 37.96 & 93.98 & 56.02 \\
\hline 12 & Kalimantan Barat & 30.5 & 65.5 & 35 & 36.48 & 75.33 & 38.85 \\
\hline 13 & Kalimantan Timur & 30.5 & 74.9 & 44.4 & 39.63 & 92.39 & 52.76 \\
\hline 14 & Rata Rata Nasional & 29.7 & 67.8 & 38.1 & 38.03 & 76.19 & 38.16 \\
\hline 15 & Bangka Belitung & 29.5 & 69.1 & 39.6 & 35.7 & 64.57 & 28.87 \\
\hline 16 & Riau & 29.5 & 74.5 & 45 & 43.19 & 86.39 & 43.2 \\
\hline 17 & Sulawesi Utara & 28.7 & 68.4 & 39.7 & 38.85 & 83.99 & 45.14 \\
\hline 18 & Sulawesi Selatan & 28.4 & 68 & 39.6 & 32.46 & 86.91 & 54.45 \\
\hline 19 & Nusa Tenggara Timur & 28 & 62.2 & 34.2 & 27.82 & 60.63 & 32.81 \\
\hline 20 & Bengkulu & 27.6 & 67.3 & 39.7 & 34.12 & 85.56 & 51.44 \\
\hline 21 & Sumatera Barat & 27.3 & 66.9 & 39.6 & 34.55 & 66.75 & 32.2 \\
\hline 22 & Maluku Utara & 27.3 & 64 & 36.7 & 37.53 & 75.85 & 38.32 \\
\hline 23 & Sulawesi Barat & 26.9 & 65.5 & 38.6 & 34.91 & 62.99 & 28.08 \\
\hline 24 & Lampung & 26.9 & 69.8 & 42.9 & 30.97 & 61.94 & 30.97 \\
\hline 25 & Jambi & 26.9 & 66.9 & 40 & 35.17 & 64.83 & 29.66 \\
\hline 26 & Kalimantan Utara & 26.5 & 61.5 & 35 & 35.43 & 65.09 & 29.66 \\
\hline 27 & Sulawesi Tenggara & 26.5 & 66.9 & 40.4 & 36.75 & 75.07 & 38.32 \\
\hline 28 & Kalimantan Tengah & 26.2 & 60.4 & 34.2 & 37.01 & 74.8 & 37.79 \\
\hline 29 & Maluku & 26.2 & 64 & 37.8 & 36.48 & 65.62 & 29.14 \\
\hline 30 & Kalimantan Selatan & 23.3 & 59.3 & 36 & 36.22 & 74.54 & 38.32 \\
\hline 31 & Gorontalo & 23.3 & 62.5 & 39.2 & 31.23 & 60.89 & 29.66 \\
\hline 32 & Sulawesi Tengah & 22.5 & 65.1 & 42.6 & 39.63 & 84.51 & 44.88 \\
\hline 33 & Papua & 22.2 & 61.5 & 39.3 & 29.13 & 60.89 & 31.76 \\
\hline 34 & Nusa Tenggara B arat & 21.5 & 63.3 & 41.8 & 34.65 & 62.73 & 28.08 \\
\hline 35 & Papua Barat & 19.3 & 58.5 & 39.2 & 28.87 & 59.84 & 30.97 \\
\hline
\end{tabular}

Source: Data processed by researchers

\section{Method}

This is a systematic review of the literature, which explains how the research and development methodology is used to combine and evaluate research that is relevant to the core of a particular topic. The purpose of a systematic review of the literature is to examine, identify, evaluate, and interpret all research on an interesting phenomenon with a variety of questions in certain appropriate research (Triandini, et.al 2019). This study employs descriptive analysis, which is a systematic presentation of the data obtained, followed by an explanation and justification for 
the reader. This study consisted of six stages. To begin, it examines poverty and welfare in light of the financial sector's role. Second, define issues surrounding Financial Literacy and Inclusion. Thirdly, after reviewing data on Indonesia's financial literacy and inclusion, Fourth, formulating problems that are related to the study and analysis of the problems. Fifth, collect data and materials relevant to the problem's focus to bolster the analysis's strength. Sixth, analyzing and presenting the impact of Financial Literacy and Inclusion, which has the potential to provide numerous benefits to the community, regulators, government, and private sector, ultimately resulting in poverty reduction. The ease with which the community can utilize banking services is expected to benefit the household economy and family welfare. Although not directly applied, because this research can be analyzed and studied through various journals and books.

\section{Findings and Discussion}

\section{a. Poverty and Prosperity in Indonesia}

Brilianti and Kautsar (2020) explained that in order to track the progress of the Indonesian people's welfare, the Central Statistics Agency (BPS) (2019b) publishes a People's Welfare Indicator Report each year. The report indicates that the Indonesian people's welfare is measured in terms of population, health and nutrition, education, consumption levels and patterns, housing and the environment, poverty, and other social issues. Among these eight indicators, poverty is one that is used to assess the welfare of the Indonesian people. As a result, poverty is used as a proxy for welfare in this study. Indonesia has a diverse range of geographical conditions, which means that the poverty rate varies by region.

Rural areas had a higher poverty rate than urban areas until 2019. In Indonesia, 9.99 million poor people live in urban areas, while 15.15 million live in rural areas (Central Bureau of Statistics, 2019b). Due to the diversity of poverty conditions, the Indonesian people's welfare status varies as well. Due to the diversity of poverty and welfare conditions, it is easier for the poor in urban areas to escape poverty than it is for the poor in rural areas. This is demonstrated by the fact that urban poverty has a lower depth index than rural poverty. In 2019, the urban poverty depth index was 1.05, while rural poverty depth was 2.18. (Central Bureau of Statistics, $2019 \mathrm{~b}$ ). On the basis of these conditions, it can be concluded that attaining a high level of welfare in urban areas is easier than in rural areas.

\section{b. The Effect of Financial Literacy on Family Welfare}

Financial literacy, according to OJK (2017), is not only about knowledge, ability, and public trust in financial institutions, but also about public attitudes toward finance. The level of financial literacy possessed by a community can also contribute to a country's economic growth (OJK, 2016). This is because individuals who are financially literate will have a better understanding of the financial sector, allowing them to take advantage of financial products and services that benefit their welfare. Additionally, individuals with a working knowledge of finance will be able to safeguard themselves against potential financial losses (OJK, 2016).

Several studies have previously examined the relationship between financial literacy and community welfare. Jappelli and Padula (2011) conducted research on the relationship between Financial Literacy and household wealth. Financial literacy has a positive and significant effect on wealth, according to research. This is demonstrated by a multi-period analysis of 11 European countries in 2003 (wave 1) and 13 European countries in 2006. (wave 2). The results 
of wave 1 analysis indicate that for every point increase in Financial Literacy, household wealth increases by $9 \%$. Meanwhile, wave 2 demonstrates that for every point increase in Financial Literacy, household wealth increases by 11.2 percent. Purniawati (2017) emphasized the detrimental effects of consumptive behavior on family welfare. This study demonstrates that both Javanese and Bugis families need to strengthen their financial literacy skills in order to manage their finances effectively and thus improve their welfare. Additionally, it was explained that Financial Literacy has an effect on portfolio diversification and investment decisions (Hastings \& Mitchell 2011). Financial literacy has the potential to have an effect on Family Welfare (Van Rooij et al. 2011; Huston 2010).

According to Irawan and Setiawan (2018), families that lack financial literacy and financial planning face difficulties achieving their financial goals. Literacy is becoming increasingly important for household decision-making regarding how to invest wealth and how much to borrow in the financial markets. Financial literacy also has far-reaching implications for the economy's overall stability. Financial literacy is critical on the asset side, as financial products have become increasingly complex. Even for straightforward products such as savings and insurance, there are frequently multiple options and distinct contracts, complicating the decision-making process. In many countries, households are more exposed to financial risk as a result of broader economic policy shifts. Improving financial literacy will help close the gap between financial capability and family welfare. Financial literacy for families is a must-have skill that must be possessed by someone who is in charge of the family's finances. Financial Literacy ensures that the family's income is spent appropriately, at the right time, in the right place, at the right price, and with the right quality.

\section{c. The Effect of Financial Inclusion on Family Welfare}

Multazam and Susamto (2017) published a study examining the effect of credit and savings/investment on household income, consumption expenditure, and housing facilities. The study analyzed data from the Indonesian Family Life Survey from 2000 to 2007. The researcher used panel data regression analysis to determine the impact of financial inclusion on people's welfare. To address these issues, one strategy that has been implemented is Financial Inclusion, which entails making it easier for the public to access financial services provided by banks. This may encourage individuals to save money and utilize bank-provided financing. The study's findings indicated that the amount of credit had a significant effect on household income. Credit and savings/investment have a significant effect on household consumption expenditures. The ease with which the community can access banking is expected to benefit the household economy and the community's welfare.

Hasan (2020) explains that certain household demographic characteristics, such as being well educated, having a family, having a fixed income, being happy, and having a positive attitude, contribute to households having good financial inclusion, namely good welfare. The use of formal/bank deposit products benefits bank lending. This means that saving products and bank loans can complement one another. This means that the relationship established through savings can be used to mitigate information asymmetry in obtaining loans, particularly when large sums of money are required.

Dixit and Ghosh (2013) concluded from their research on the impact of financial inclusion on poverty in India that providing access to financial services has the potential to break the poor's vicious cycle of poverty by instilling a culture of saving and thrift and enabling 
the development of efficient and low-cost payment mechanisms. Sanjaya (2014) discovered that financial inclusion via microcredit programs can help the poor improve their social and economic status. Numerous research findings indicate that financial inclusion benefits poverty reduction efforts. In line with Park and Mercado's research in Fitriah and Ichwanudin, W. (2020), financial inclusion significantly reduces poverty and income inequality in 37 developing countries in Asia.

According to Indrajaya.I.G.B and Kusuma.A.A.N.J.K, 2020, providing access to financial services has the potential to lift the poor out of poverty. Financial inclusion will foster a saving culture and enable the development of efficient and low-cost payment mechanisms. Access to financial services is critical because it has an effect on changing consumption patterns, investment, education, and inclusive growth (Dixit and Ghosh, 2013). This is also supported by research conducted by Allen et al. (2016), which discovered that having commercial banks can help improve poor people's access to financial services in Kenya

\section{Conclusion}

Based on the results of the study, it can be concluded several things as follows

1. The poverty line is a point at which an individual is classified as poor or not. In Indonesia, the BPS calculates the standard poverty line using the results of the National SocioEconomic Survey (Susenas) (Isdijoso, Suryahadi, \& Akhmadi, 2016). In this study, poverty serves as a proxy for welfare. Indonesia has a diverse range of geographical conditions, which means that the poverty rate varies by region.

2. Financial literacy has the potential to have a detrimental effect on family welfare (Van Rooij et al. 2011; Huston 2010). Financial literacy for families is a must-have skill that must be possessed by someone who is in charge of the family's finances. Financial Literacy ensures that the family's income is spent appropriately, at the right time, in the right place, at the right price, and in the right quality.

3. Financial inclusion can provide numerous benefits to the public, regulators, government, and private sector, including increased economic efficiency, support for financial stability, support for financial markets, creation of new market opportunities for banking, positive contributions to sustainable local and national economic growth, and reduction of inequality and the rigidity of the low-income trap, all of which contribute to improved people's welfare. The ease with which the community can utilize banking services is expected to benefit the household economy and family welfare.

\section{References}

1) Adi, Isbandi Rukminto. 2013. Kesejahteraan Sosial, dan Kajian Pembangunan. Jakarta: PT Raja Grafindo Persada.

2) Adriani.D \& Wiksuana, 2018. Inklusi Keuangan Dalam Hubungannya Dengan Pertumbuhan Umkm Dan Tingkat Kesejahteraan Masyarakat Di Provinsi Bali. E-Jurnal Manajemen Unud, Vol. 7, No. 12: 6420 - 6444 Issn: 2302-8912.

3) Badrudin, Rudy. 2012. Ekonomika Otonomi Daerah. Yogyakarta: UPP STIM YKPN.

4) Brillianti F \& Kautsar A, 2020. Apakah Literasi Keuangan Memengaruhi Kesejahteraan Rumah Tangga di Indonesia? Kajian Ekonomi \& Keuangan Volume 4 Nomor 2. 
5) Dixit, R., and Ghosh, M. (2013). Financial Inclusion for Inclusive Growth of India a Study of Indian States. International Journal of Business Management \& Research, 31), 147-156.

6) Fahrudin (2012) Pengantar Kesejahteraan Sosial, 2012, PT. Refika Aditama,

7) Farah Margaretha \& Siti May Sari, 2015, „Faktor Penentu Tingkat Literasi Keuangan Para Pengguna Kartu Kredit di Indonesia ${ }^{e e}$, Jurnal Akuntansi dan Investasi, Vol. 16, No.2, Hal. 132-144.

8) Fitriah, Ichwanudin. W (2020) Faktor-Faktor Yang Mempengaruhi Inklusi Keuangan (Studi Pada Mahasiswa Magister Manajemen Universitas Sultan Ageng Tirtayasa) Vol. 4 No. 2, 2020 hh. 94-108 | e-ISSN: 2599-0837.

9) Hasan, 2020. Inklusi Keuangan Rumah Tangga Di Indonesia Laporan Akhir Penelitian.

10) Huston, J Sandra, 2010, „Measuring Financial Literacy“e, The Journal of Consumer Affairs, Vol. 44, No. 22, Hal. 296-136.

11) Irawan \& Setiawan. A, 2018. Literasi Keuangan Terhadap Kesejahteraan Keluarga Melalui Perencanaan Keuangan (Studi Demografi Masyarakat Kota Tanjung Balai). Vol. 8 No.2 Januari 2018 ISSN: $2087-4669$.

12) Indrajaya.I.G.B \& Kusuma.A.A.N.J.K, 2020. Analisis Pengaruh Inklusi Keuangan Terhadap Tingkat Kemiskinan Dan Ketimpangan Pendapatan Masyarakat Di Kabupaten/Kota Provinsi Bali. E-Jurnal Ekonomi Pembangunan Universitas Udayana, Vol.9.No.5. 993 - 1022 ISSN 2303-0178.

13) Kartawinata \& Mubaraq, 2018. Pengaruh Kompetensi Keuangan Terhadap Literasi Keuangan Bagi Wanita di Makassar Oikos: Jurnal Kajian Pendidikan Ekonomi dan Ilmu Ekonomi, ISSN Online: 2549-228 Volume II Nomor 2.

14) Lusardi. A, Mitchell, Olivia. S, 2013. The Economic Importance Of Financial Literacy: Theory And Evidence National Bureau Of Economic Research 1050 Massachusetts Avenue, Working Paper 18952Cambridge, Ma 02138.

15) Lusardi, A \& Mitchell, O, 2013. The Economi Importance of Financial Literacy: Theory and Evidence ${ }^{e e}$, Nber Working Paper Series, No. 18952, Hal. 1-63.

16) Multazam M.A \&Susamto A.A, 2017. Pengaruh Financial Inclusion Terhadap Kesejahteraan Masyarakat: Analisis Level Rumah Tangga, Tesis Agama dan Lintas Budaya.

17) Nurulhuda E.S, Lutfiati. A, 2020. Analisis Faktor-Faktor Yang Mempengaruhi Literasi Keuangan (Studi Kasus Mahasiswa Fakultas Ekonomi Dan Bisnis Universitas Islam As-Syafi'iyah). Kinerja Jurnal Ekonomi Dan Bisnis Vol. 2 No. 2 - Juni 2020.

18) N. Triana, 2019. Peranan Modal Sosial Dalam Meningkatkan Kesejahteraan Keluarga Pra Sejahtera Di Kecamatan Pallangga Kabupaten Gowa

19) Ratnawati.T, Rohmasari. F, Lokajaya.IN, 2017. Strategi Financial Literacy \& Financial Inclusion Sebagai Trigger Kesejahteraan Masyarakat Industri Kecil Kawasan Wisata Giri Kabupaten Gresik Jawa Timur. Jurnal Penelitian LPPM Untag Surabaya $\quad$ September 2017, Vol. 02, No. 01, hal 57 - 64 EISSN: 2502-8308 P-ISSN: 2579- 7980.

20) Reni Tri Purniawati. R. T \& Lutfi, 2017. Literasi keuangan dan pengelolaan keuangan keluarga dalam perspektif budaya Jawa dan Bugis. Journal of Business and Banking. ISSN 2088-7841. Volume 7 Number 1. pp. 31- 46.

21) Sanjaya, I.M, 2014. Inklusi Keuangan dan Pertumbuhan Inklusif sebagai Strategi Pengentasan Kemiskinan di Indonesia. Bogor: Institut Pertanian Bogor. Retrieved from: http://repository.ipb. ac.id/handle/123456789/71330.

22) Suaebah.E, Suciati.F, Zaky.M, 2021. Literasi Keuangan Melalui Inklusi Keuangan Untuk Meningkatkan Kesejahteraan Petani Tanaman Holtikultura

Daratan 
Tinggi Sukabumi. JIMEA -Jurnal Ilmiah MEA (Manajemen, Ekonomi, dan Akuntansi) Vol. 5 No. 3.

23) Suandi, 2014. Hubungan Modal Sosial Dengan Kesejahteraan Ekonomi Keluarga Di Daerah Perdesaan Jambi Jurnal Komunitas Research \& Learning in Sociology and Anthropology 6 (1) 38-46. DOI: 10.15294.

24) Sunarti. E, 2016. Indikator Keluarga Sejahtera: Sejarah Pengembangan, Evaluasi, Dan Keberlanjutannya, Fakultas Ekologi Manusia, IPB, ISBN: 978-602-8665-05-6.

25) Sanistasya P.A, Rahardjo K, Iqbal. M, 2018. Pengaruh Literasi Keuangan dan Inklusi Keuangan Terhadap Kinerja Usaha Kecil di Kalimantan Timur Jurnal Economia, Volume 14, Nomor 1, 48-59 P-ISSN: 1858-2648.

26) Telaumbanua \& Nugraheni ,2018. Factors Affecting the Housewife Efforts in Improving Social Welfare, Jurnal PKS, Vol 17 No 3 (217 - 226).

27) Widayati. I, 2012. Faktor-Faktor Yang Mempengaruhi Literasi Finansial Mahasiswa Fakultas Ekonomi Dan Bisnis Universitas Brawijaya Asset: Jurnal Akuntansi Dan Pendidikan, Volume 1, Nomor 1.

28) Widyastuti, 2012. Analisis Hubungan Antara Produktivitas Pekerja Dan Tingkat Pendidikan Pekerja Terhadap Kesejahteraan Keluarga Di Jawa Tengah Tahun 2009. Economics Development Analysis Journal 1

29) Yilmaz Bayar, Marius, \& Gavrilete, 2018. Inclusion and Economic Growth: Evidence from Transition Economies Of European Union. Journal Internasioanl JIFE, Volume 18, Number 2, ISSN: 1555.

30) Yushita. A.N, 2017. Pentingnya Literasi Keuangan Bagi Pengelolaan Keuangan Pribadi. Jurnal Nominal / Volume Vi Nomor 1.

31) Yutaka Kurihara, 2013. Does Financial Skill Promote Economic Growth? International Journal of Humanities and Social Science Vol. 3 No. 8. Nagoya 4538777, Japan.

32) Zainuddin. $S$ dan Erwin, 2018. Implementasi Financial Inclusion Terhadap Usaha Mikro Kecil Dan Menengah (Umkm) Dengan Kearifan Lokal Sebagai Variabel Moderating. Journal of Institution And Sharia Finance: Volume I Nomor 1. 